Article

\title{
Education for Wonder
}

\author{
Haydn Washington
}

PANGEA Research Centre, School of Biological, Earth and Environmental Sciences, University of New South Wales, Sydney, NSW 2052, Australia; h.washington@unsw.edu.au

Received: 6 July 2018; Accepted: 17 August 2018; Published: 21 August 2018

\begin{abstract}
This article argues that rejuvenating a sense of wonder towards nature is essential to ecocentric education and to finding a sustainable future. It examines the barriers that block education for wonder and looks at the issues around education for wonder in the home, at school, at university, and in the community in general. It considers the scale of a natural area in terms of wonder education, and ways of teaching wonder in school that increase wonder rather than isolate the student from nature. It also considers the issue of an "education for sustainable development" influenced by anthropocentrism, in contrast to an environmental education where some scholars accept the intrinsic value of nature. It discusses the need to balance "facts" in education with ethics. The article concludes by summarizing the steps needed to re-educate for wonder.
\end{abstract}

Keywords: wonder towards nature; ecocentric education; ecocentrism; anthropocentrism; environmental education; experiential education

\section{Introduction}

Much official educational policy—including that which relates to the environment-makes scant reference to nature and shows a largely analytic/instrumental/invasive rationality [1]. Bonnett [1] notes that such education reflects a worrying banality, lacking any understanding that science education should seek to develop an appreciation of nature. Bonnett [1] (p. 2) asks some important questions in regard to how we teach about nature:

What is nature and what is our place in it? How can we know nature and what should be our attitude towards it? Against what criteria should humankind judge its progress/success/flourishing in relation to the natural world?

These are important questions, yet ones rarely asked in our education system. Bonnett [1] argues that the value of a more intimate, intuitive, non-logical style of encounter with the world needs to be acknowledged.

Hence why we need ecocentric education. Ecocentrism is a philosophy or worldview that places intrinsic value on all living organisms and their natural environment (including geodiversity), regardless of their perceived usefulness or importance to human beings [2]. Ecocentric education is thus arguably education that focuses on the intrinsic value of nonhuman nature and assists humanity to find an ecological ethics that allocates moral consideration to the nonhuman [3]. However, the background for this Special Edition noted that ecocentric education is a broad church. It can include conservation (e.g., [4,5]), education for deep ecology (e.g., [6]), post-humanist education (e.g., [7]), animal rights (e.g., [8]), and animal welfare education (e.g., [9]). It has also been argued that ecocentric education focuses on unity between environmental (or ecological) ethics and sustainability (e.g., [10]).

How does one assist the promotion of ecocentric education? Arguably this means we need to help humanity feel that nature has intrinsic value that should be morally considered [3]. That means that humans, especially children, need the opportunity to form a personal connection to the nonhuman. 
A key way to do this is experiential education that increases the time children spend in nature, and also facilitates children forming a bond with nature. Abram [11] (p. 50) speaks eloquently about why children need time to ramble though nature and find things for themselves: "Things catch our eye and sometimes refuse to let go, they 'grab our focus' and 'capture our attention'" and finally release us from their grasp only to dissolve back into the overabundant world". Bonnett [7] (p. 196) similarly notes, "Things can summon our attention and in this way animate our being" and acknowledging these can "gift inspiration and lead us to new insights concerning the nature of sustainability and a frame of mind that it implies." Given society is more divorced from nature than ever before [12,13], ecocentric education is arguably essential if we are to reach a truly sustainable future [3,14]. Curry [3] argues direct contact with nature allows a sense of wonder, being alive, and greater creativity, social cooperation, and appreciation of boundaries. Literature in environmental and place-based education argues for direct experience with the natural world to develop relationships with nonhuman nature [15]. Hence what is crucially needed is experiential education out amidst nature, and for this reason we need a "Leave no child inside" movement [12] (p. 222). Given the strength of the barriers to education for wonder discussed below, arguably as a society we will not be able to reach an ecocentric worldview unless we can rejuvenate our "sense of wonder" toward nature $[3,11,14]$. The key reason is that a sense of wonder towards nature assists the deep belief necessary to take the difficult decisions that need to be taken to solve the environmental crisis $[14,16]$.

So, what is our sense of wonder? Essentially it is our love of the land, which arguably is innate in children [17], though this can been jaded during puberty, so it is buried in many adults [14,18]. It is our sense of awe, feeling part of life, of enchantment with place [19]. However, Schinkel [20] distinguishes between "wonder" as in curiosity and the type of wonder I describe above that she calls "deep wonder." Schinkel argues there is a "widely shared intuition that the capability of experiencing deep wonder at the universe and all it contains is not just educationally relevant, but lies at the heart of education" [20]. Accordingly, we need to educate effectively to retain and encourage a sense of (deep) wonder. Given that people of all religions (and philosophies) can experience a sense of wonder at nature (and its often life-changing effects), it would be perfectly appropriate if all religions, secular beliefs, and education systems sought to rejuvenate society's sense of wonder [14]. Abram [11] (p. 278) observes that a "felt mystery" underlies all society's doctrines, and this should unify many social groups and beliefs.

This article will consider the barriers to education for wonder, and how these can be overcome in the home, at school, at university and in the community overall. It also considers the best ways to teach for wonder, as well as considering whether we need a holistic environmental education rather than 'education for sustainable development' (ESD). It also considers the need to balance 'facts' with ethics. The article finishes by summarizing the key steps to re-educate for wonder.

\section{What Blocks Education for Wonder?}

Humanity today is more urbanized and less connected to nature than ever before in our history, as many have noted (e.g., [12-14]). Shepard [21] claims that our psychological development inherently calls for a childhood immersion in wild nature, and for a subsequent adolescent tutoring into mature, reciprocal, and harmonious relations with the larger natural world. We face what has been called the "extinction of experience" in regard to wild nature [13]. Philosopher Arne Vetlesen [22] argues today most people in Western society experience nature as an "abstraction." He believes that to make a difference in the real world (the social as well as the natural one), a shift must be made from theorizing nature to experiencing nature. The fact that we now physically engage less with nonhuman nature (especially in childhood) is clearly one major block to establishing and rejuvenating a sense of wonder. Another is the way our society views the world, and anthropocentrism is a key problem here $[2,7,23]$, along with our modernist worldview and the utilitarian ethics of neoclassical economics [24].

Environmental educator David Orr [25] argues that the ecological crisis is rooted in the way we educate future generations. He argues that the dominant education today alienates us from 
life in the name of human domination, fragments instead of unifies (in terms of our relation with nature), over-emphasises success and careers, separates feeling from intellect, and the practical from the theoretical, and unleashes on the world minds that are ignorant of their ignorance. If we are to change this and make education wonder-friendly, we should consider how best to encourage a sense of wonder at home, at school, at university, and in our community.

\section{Education for Wonder in the Home}

The way that parents and children interact with nature in the home is clearly important, especially as children tend to form their bond with nature during ages 7-12 [26]. How parents and family members interact with nature will affect how children in the home relate to nature. Trimble [27] (p. 131) notes, "In creating a stage for our children's stories we make choices." He argues that to do so attentively begins by thinking as a native of a region. Louv [12] notes that children strongly respond to an elder "mentor" who expresses interest in, and wonder towards, nature. Chawla [28] argues that good nature mentors demonstrate a contagious attitude of attentiveness. However, Louv [12] notes that while knowledge about a natural area is essential in a mentor, they also need passion to convey their care for life.

Louv [13] observes that our houses and our neighborhoods are not commonly designed to encourage connection with nonhuman nature. Commonly, new suburbs tend to be designed around roads and shopping malls, with no thought to connecting with nature. Parks are mostly cleared areas given over to a few exotic grasses, and maybe a tree or two (mostly not local species). Louv [13] (p. 135) notes that, "The question of human/nature kinship is one of the great architectural, urban planning, and social challenges of the twenty-first century". He argues for "restorative environmental design," where suburbia is changed to "Subutopia" [13] (p. 231). He describes wonder-friendly ideas such as the 1000-acre "Serenebe" village project near Atlanta in the US, which leaves $70 \%$ of the area as native vegetation or farmland. Its vision [13] (p. 222) is to "value nature, passion, creativity and community. We believe people can live more fully when connected to the wonder of nature".

Of course, in a world dominated by information technology (IT), there remains the key problem parents must face- - how do you get children off their computer or tablet (playing games, social media, etc.) and out into nature? Louv [13] concludes that the more time people spend in the virtual computer world, the more time they need to spend out in nature to counteract this. The "wonder of community" section considers this further.

\section{Wonder at School}

Schools should encourage wonder towards nature, but the increasing disconnect of children from nature $[12,13]$ suggests most fail to do so. Part of the problem is the idea that "education" is often seen as just about passing exams that measure memory (and possibly one form of intelligence). Even worse is the idea that education is about indoctrinating children to accept the dominant anthropocentric, modernist worldview of society [29]. Schools could alternatively be about encouraging imagination and creativity, something that Steiner education (Waldorf schooling) has long promoted. This aims to cultivate a sense of the "meaningful wholeness of nature; a wholeness from which the human being is not separated or alienated" [30] (p. 113). Cobb [26] and Louv [12] (p. 94) speak of the importance of "the ecology of imagination" for children. Child psychologist Sutton-Smith (in [31] (p. 9)) argues, "play has become too domesticated" and regimented, while playgrounds themselves have become increasingly barren. So, schools need to naturalize their schoolyards by planting locally-native species, including shrubs and groundcovers (not just trees). They need to create places where children can spend unsupervised playtime, developing their own games in nature. Hence, in ecocentric education, schools should incorporate nature's ability to enhance learning and creativity, and redefine the classroom in schools as well as universities to often include teaching in nature [13] (p. 258).

There are other important aspects of bringing wonder into school education (apart from the physical school property), the first is the curriculum or syllabus of what is to be taught. The curriculum 
is the totality of student experiences that occur in the educational process [32]. A syllabus is an academic document that sets out course information and defines the detail of what is to be taught. It is descriptive (unlike the specific curriculum). In some countries (e.g., Australia), the curriculum is set nationally, but the syllabus teachers must follow is set by each state. A sense of wonder at nature is absent in most school curricula or syllabuses around the world. In fact, Bonnett [1] notes that most curricula are moulded by the general anthropocentrism of Enlightenment humanism. This urgently needs to change. Bonnett [1] argues that our environmental predicament is a crisis not simply of our physical survival, but of our spiritual survival - that is, our understanding of what we are and how we should relate to the world around us. He argues the curriculum should develop the right relationship with nature and thus offer a fuller understanding of what truly should count as "human flourishing". Bonnett [1] (p. 10) argues education should involve "an understanding of our own nature and an appreciation of nature's value that truly transcends the instrumental". There are so many disciplines in schooling where wonder can easily be integrated into the syllabus. For example, science (the kinship of life); geography (sense of place); drama (role-playing becoming local species or doing a "mock trial" about protecting local nature); English (the poetry and prose of wonder-such as the American nature writers Thoreau, Muir, Leopold, Carson, etc.); and art (expressing nature through artworks). However, most curricula/syllabuses do not acknowledge the problem of "Nature Deficit Disorder" [12] and do not prioritize encouraging a sense of wonder. The task of rejuvenating society's sense of wonder towards nature would be so much easier if they did.

In regard to a curriculum, Lautensach [33] argues that an effective "Transition Curriculum" must transcend the conventional discourse about "security", "sustainability", "progress", and "growth" and counteract the anthropocentric conditioning that pervades mainstream educational practice. A key part of such an ecocentric syllabus is mandating trips to natural areas, especially in primary schools. Fisher [34] argues that a naturalistic and experiential environmental education would design its curriculum not to satisfy industry but to reclaim relations with wild nature. Children must get out into nature and interact with it to bond with it, to feel that sense of wonder that (hopefully) may stay with them for the rest of their lives. This is the "unfolding" of a child's solidarity with nature that Abram [11] speaks of.

My argument that primary schools need to be prioritized regarding education for wonder is because of the essential need for children to have access to nature from ages 7-12. Edith Cobb (in [31] (p. 28)) emphasizes the potential of this time, when children are "in love with the universe" and "poised halfway between inner and outer worlds". Here, she says, lie "latent power and purpose, the seeds of the writer's art, the painter's vision, the explorer's passion" (Ibid). Wells and Leckies [35] similarly found that adult concern for the environment derived from participating in "wild nature activities" before the age of 11 . Hence, primary children critically need to be taken on field trips out into wild nature.

Some positive change however is happening. Finland has encouraged environment-based education and has moved a substantial amount of classroom experience into natural settings [13]. Finnish schools have a focus on outdoor education, and this includes camp schools in the lower grades (11-12-year-old pupils). Typical themes for camp schools (3-5 days in length) are nature and environment and the building of pupils' social competence [36]. It is also worth distinguishing school programs working on sustainability from those working on education for wonder. For example, "ecoschools" are a world-wide movement started in the UK, where 18,000 schools are registered and 1200 schools currently hold the internationally recognized "Eco-Schools Green Flag" (https: //www.eco-schools.org.uk/about-us/). However, this program has 10 topics, none of which relate to outdoor experiential education for children. Only one topic peripherally relates to education for wonder, which is "School Grounds", which says such grounds are "a fantastic environment in which to let the imagination run wild. How will your school make the most of its outside space?" However, ecoschools could expand their ethos to act as a focus for wonder education. However, 
education for wonder should not have to be "add ons", it should be fundamental, spelled out in the curricula/syllabuses of all education departments everywhere.

\section{Education for Wonder in Schools Can Be Fun}

An important point to consider is "fun". Education for wonder should be fun in schools. Washington [14] discusses the work of Cornell [37] and Young et al. [38] in regard to nature education being fun. Joseph Cornell [37] in Sharing Nature with Children lists a whole range of games that mentors can use with primary children in natural areas. He argues [37] (p. 9) we need to use nature to "stimulate joyful, enlightening insights and experiences-for ourselves, as well as for our children and child-friends". Cornell notes [37] (p. 11) that his sharing nature activities are so popular.

$\ldots$ because in addition to teaching ecology creatively, these games help people experience a profound sense of joy, serenity and belonging to the natural world.

Cornell [37] (p. 13) notes some "suggestions for good teaching" based on basic attitudes of respect for children and reverence for nature. These are: Teach less and share more; Be receptive; Focus the child's attention without delay; Look and experience first, talk later; A sense of joy should permeate the experience. Cornell [37] lists an 'Explorers Guide' for children to fill in (which includes a 'vertical poem') and a 'Sunset watch' sheet. He concludes with the 'Silent Sharing Walk', which is where a small group walks in silence amongst wild nature [37] (p. 156). He notes this is potentially the most powerful of all games. Cornell [37] (p. 156) states that the silence and harmony of such moments, especially at dawn or dusk, create an awareness that "we are sharing the world with all living thing'".

Another book describing exercises to connect to nature is Coyote's Guide to Connecting with Nature [38]. This book discusses core routines, child passions, the "Book of nature," the natural cycle, and indicators of awareness. It encourages routines such as a "sit spot" you visit regularly, the "story of the day" where you report on what nature graced you with, "expanding your senses", "questioning and tracking", and "wandering". For anybody wanting to become a mentor (who may need more detailed information on nature games to play with children) this is an important resource. However, Cornell's [37] Sharing Nature with Children is much simpler to use for primary teachers (or occasional mentors).

Finally, it is worth emphasizing that I am arguing for children to have fun though outdoor experiential education in nature, employing their observation, creativity and imagination. Others (e.g., [39]) have spoken of being wary of "warm glow" approaches to sustainability education. However, the fun from interacting directly with wild nature through experiential education (and using one's imagination and creativity) is a very different thing from approaches to sustainability suggesting that "everything is fine" and that society can easily solve the environmental crisis. I argue here simply that education for wonder can (and should) be fun for children when outside in nature. The grim reality of environmental problems (along with their difficult if exciting solutions) will also have to be part of children's education at some stage [16].

\section{Education for Wonder at the University Level}

Effective education for wonder should not just stop when school ends, it should continue right through tertiary education (and on into continuing education programs for adults). However, most universities (and other tertiary education institutions) do not foreground either ecocentrism or a sense of wonder. Curry [3] notes that universities increasingly are led by the anthropocentric corporate agenda. Curry also notes that there is a split in higher education between "science materialists" and "cultural constructivists", with each trying to capture nature as a whole for their own one-sided versions [3]. Both sides, however, regard nature as just passive "resources". Philosophy and ethics classes would usually consider ecocentrism, but few (if any) tertiary education institutions have a mission, vision or goal that supports ecocentrism and the "Rights of Nature" [40]. 
Similarly, few universities acknowledge just how important a sense of wonder can be in terms of moving society toward a meaningful sustainability [16]. Few (if any) have goals to encourage a sense of wonder toward nature or discuss an "Earth ethics" [41] in their courses. Louv [12] also notes the virtual banishment of natural sciences from academia. Environmental science/studies follows a similar trajectory, with less courses now being taught, a trend proceeding in exactly the wrong direction to what is needed.

\section{Education for Wonder at the Community Level}

There are other things we can do as a community to educate for wonder. One important aspect for both children and adults are nature rituals such as the "Council of All Beings" [14,42,43]. These can also be adapted for children (see http:/ / www.rainforestinfo.org.au/deep-eco/coab-youth.htm). However, such rituals are also important in rejuvenating the sense of wonder in adults. Another important idea is that of "Nature Clubs", where a group of parents in an area sign up their families to various trips to natural sites around their homes [13]. Louv [13] argues that Nature Clubs can be quite successful in breaking a child free of his/her "technology" (such as computers). Nature Club days can also become key social events for children (and adults), being simply "lots of fun". They can thus build a sense of community (social capital) in a world where many people feel increasingly isolated (e.g., [44]).

Another international group that Louv [13] suggests is "Exploring a Sense of Place" (http:/ / www. exploringsenseofplace.org/) that takes people on treks into their local ecosystems. "Nature camps" are also run by many groups. There are also groups such as "Outward Bound" (https://www. outwardbound.net/) or the Duke of Edinburgh Award (http:/ /www.intaward.org/about-the-award) that teach children survival skills in nature through walking and camping in wild places. The key hurdle may be the initial agreement by children to try them out. Accordingly, children should be advised of what Louv [13] reports regarding Outward Bound-that an extraordinary $72 \%$ of participants said it was one of the best experiences of their life.

Another useful community strategy is to create a new institution, the "Life Center" [45]. While a few organizations with such names already exist, these would be new public institutions (probably established by local government) that focus on the processes of life, and the well-being of people and nature. Networks of Life Centers would operate to focus on the idea of "healthy people on a healthy planet". They could play a direct educational role, act as discussion forums for issues such as a sense of wonder, and act as repositories of sustainability information. Such centers could fill a serious gap in the institutional structure of society-an actual institution focusing on wonder, reconnecting to nature and sustainability. It is clear from the above strategies that without waiting for government to change city or town designs, or radically update education curricula/syllabuses to foreground wonder, we-as a community—can carry out a whole range of activities that reconnect us with nature and the experience of wonder (and fun) that this brings with it.

One potentially powerful opportunity is the influence that 'faith communities' could have in regard to promoting a sense of wonder. I have personally worked constructively in Australia with both the Faith Ecology Network and the Brahma Kumaris to discuss ecocentrism and a sense of wonder. An example of the potential power of religious support for nature is the Pope's Encyclical "Laudato $\mathrm{Si}^{\prime \prime}$, which supports a reverence for life and the responsibility to protect it [46]. If all religions were to support the intrinsic value of nature and seek to rejuvenate society's sense of wonder, then society's worldview and ethics might change markedly and quickly towards ecocentrism. This could be a major step forward towards a sustainable future [14,16].

\section{The Scale of Wonder-from Backyard to Wilderness}

In regard to education for wonder, it is important to discuss the issue of the scale of the natural area (in regard to size) that people interact with. Many scholars argue passionately for the importance of "wilderness" (being essentially defined as large natural areas [47]) in terms of how it teaches us wonder (e.g., [14,48,49]). Others such as Nabhan and Trimble [31] and Louv [12] focus on small, 
local wild places, and their importance to children. Louv [12] (p. 95) notes that "transcendent childhood experiences" could be evoked by environments as small as a patch of weeds at the edge of a porch. He argues creeks and stands of trees are entire universes to a young child. However, I would like to highlight the essential need for both small and large areas in regard to education for wonder. There is actually no conflict. Children do need local wild places growing up, even if they are only half an acre next to a creek, or the pond with Newts, both of which Weber [50] found wondrous. Such small areas allow unsupervised play in amongst nonhuman nature, our kin. There they will be able to marvel at insects, birds, and mammals. They will find weird-shaped rocks, strange bits of wood, amazingly-colored feathers, and perhaps even odd shells. This is the "geography of childhood" that Nabhan and Trimble [31] speak of. An anonymous reviewer (pers. comm.) of this paper also raised the question of places where nature and culture are strongly interrelated. This may be a historical, religious or sacred place. These can also be powerful places to experience wonder. In such places one may find a real (not virtual) experience that is both natural and cultural. The nature of the place and its history will affect this. Countries where nature is close by to cities (e.g., Australia) may mean the focus is on the natural wonder of places. Countries that have greater development (such as Europe) may focus on the artistic/historic/cultural dimensions of place.

Local places of wonder are thus essential in terms of forming and rejuvenating a sense of wonder in both children and adults. Of course, decades ago there was less fear of "stranger danger" and children were allowed to wander off exploring - to find wonder (I was myself one). Today, fear for our children often acts to imprison them away from natural areas [13]. Local wild places are especially important for younger children. However, they are just one end of a wild spectrum stretching to larger reserves, to national parks and then to large wilderness areas. Larger areas such as wilderness also have a powerfully positive role in the sense of wonder $[14,48,49]$. The power of bonding with nature over several days hiking in a wilderness can be life-changing. Larger areas such as wilderness are thus important for older children and adults in terms of catalyzing and rejuvenating the sense of wonder. They are also special places to undertake a "Rite of Passage" during adolescence (e.g., www.ritesofpassagevisionquest.org). Thus, small areas and large areas are both integral and complementary to the geography of wonder. We need them both.

\section{Ways of Teaching Wonder, Not Isolation}

Gary Nabhan [51] (p. 39) has noted that he learned more about the natural world while "playing hookey" than he ever learned in the classroom. David Abram [11] speaks of being a child who was endlessly fascinated by frogs and birds. Then at school a teacher told him about "atomic structure", stating that all they saw was an "illusion" made up mostly of empty space. Abram reports he walked around in bedazzlement, not trusting the living world he loved to be real (rather than illusory). Later, a teacher taught him that behavior in animals was "programmed" by their genes. This transformed his experience of the natural world. He found he was no longer noticing birds and found it harder to listen to them. Abram said he had (he realized later) defined away all the creativity and meaning of those bird voices, so there was then no longer anything being said [11]. Hence the bird calls faded into the background of a life increasingly focused on purely human concerns. He said his animal senses began to shut down, his eyes were no longer dazzled by the turquoise beetles or the high-stepping heron. The teaching about anything natural in his schooling was done indoors. The world accessible to our senses—hillsides and rain and flocking birds—came to seem a secondary dimension, a largely illusory field of appearances waiting to be penetrated and dissipated by the human mind [11]. The animate nature that our senses revealed was no longer fundamental to him. Abram [11] concluded that this might explain why few people seemed upset about nature's rapid destruction or accelerating species extinctions. Observable nature had become what Abram calls a "derivative reality", a realm useful for its resources, or as a dump site for toxic chemicals.

Now Abram recovered from this disturbing "distancing" from nature, indeed he has written two key books in regard to wonder-The Spell of the Sensuous [52] and Becoming Animal [11]. It is a sign of 
hope that he was able to recover, as this means others can too. However, his experience shows how critical it is regarding how one teaches in school. Weber [50] discusses the key problem of science and biology, that they distance themselves from nature, so we only consider it on the dissecting table. Louv [12] notes we have industrialized the classroom, and nature seems to have dropped off the curriculum. Louv [12] (p. 137) notes that we pour money into educational electronics and allow "less and less fashionable but more effective tools to atrophy". In this regard, he notes the death of natural history in higher education. Zoologist Richard Stebbins (in Louv [12] (p. 140)) reports the "waning of awe (or simple respect) toward nature" that he sensed in each successive generation.

So, the way we teach can either aid wonder, or reduce it by removing the mystery and magic of life. Some students may never recover from the disenchantment that Abram describes, of a clinical anthropocentric education without wonder, of a science that sees nature as simply dead [22]. Their connection with nature may have been eroded and buried in school precisely because of the way that science was taught, through a scientism approach where classical scientific thinking is seen as the arbiter of good thinking as a whole [53]. This is a great shame, and a major problem in terms of education for wonder. For this reason, teachers need to be mentored about how best to teach for wonder. A key point here that Nabhan [54] (p. 88) makes is that "Learning has to come from doing". In other words, children need family, schools and teachers to take them out into nature to teach about its wonder.

\section{Environmental Education or Education for "Sustainable Development"?}

We should also consider "education for sustainable development" (ESD). This is often considered the same as environmental education (EE), however Bonnett [53] argues 'environmental education' is a wider term. It is worth noting that the relationship between EE and ESD remains contested in academia [55]. Indeed, Jickling and Wals note that, in one questionnaire, over half of the educators sampled agreed with a proposition that ESD should be abolished as a concept [55]. My discussion of EE and ESD here generally falls into line with that of Jickling and Wals [55], Bonnett [7], and Kopnina [56-58]. EE arguably goes back to the time of Rousseau in the 18th century, where the emphasis in the earlier stages of education was on learning through direct observation and physical activity in the natural environment [53]. However, the curriculum now tends to give prominence to ESD rather than to an environmental education where some scholars argue it should uphold the intrinsic value of nature (e.g., [7,39,53]). Sitka-Sage et al. [39] argue the role of environmental educators ought to be provoking discussion and involving children in thinking about, acting with, and relating to "things" with ecological humility as "ethically significant others". Hence EE should also work to develop the eco-critical dispositions, historical literacies and imaginative sensibilities to teach students how to learn in ways that challenge human supremacy [53]. Of course, both environmental education and ESD contain a range of views. My point here is to suggest that ESD tends to be more dominated by an anthropocentric (or neoliberal [55]) worldview that doesn't speak of nature having intrinsic value $[1,7,56,58,59]$. Indeed, ESD (through globalization) can serve (or at least not question) a neoliberal agenda [55]. EE by contrast does have proponents who argue the intrinsic value of nature $[1,7,53,55,56]$. Kopnina [56] notes that the early proponents of EE emphasized that it has as its goal a positive change in human relationship with nature. Much environmental education aims at changing learner behaviour, including attitudes, beliefs and values [60]. Kopnina [56] also notes that while the Belgrade Charter (one Global Framework for EE [61]) is more focused on the environment than on human development, emphasizing the need for environmental protection from human activities, ESD only places further emphasis on human rights issues.

Spring [62] criticises the anthropocentric approach advocated by mainstream "sustainable development". Bonnett [1] describes how sustainable development enshrines the idea that nature is just a "resource". "Sustainable development" has been said to be redolent with the general 'metaphysics of mastery' that informs modernity, and which many scholars argue is precisely the root cause of our current environmental predicament [1]. Bonnett [1] (p. 3) notes that with such humanistic hubris, 
nature is "constantly to be challenged, set in order, re-engineered, etc., to meet human needs-and often, not even this, but merely human convenience". Kopnina [56] (p. 706) argues that environmental protection in sustainable development is too often, "seen as an afterthought to all other pressing human issues such as equality, fair distribution of natural resources and human rights". She has further criticized (e.g., [57]) mainstream academic discussions around sustainable development for stubbornly maintaining an instrumental and anthropocentric worldview. Washington [16] in Demystifying Sustainability examines in detail the question, "Does 'sustainable development' equal sustainability?" and concludes that the two are quite different. The "development" in sustainable development has been subverted in common usage to mean "growth", which on a finite planet where society has exceeded ecological limits is an impossibility [59]. In this sense, "sustainable development" is an oxymoron, while sustainability itself most certainly is not $[7,16]$. There are of course many ideas of "sustainability", and I support a definition that sees sustainability (especially ecological sustainability) as first and foremost being about solving the environmental crisis [16].

In regard to the specific area of education for "sustainable development", Jickling and Wals [55] argue that EE is being significantly altered by globalizing forces, witnessing the effort to convert EE into ESD (with a more neoliberal focus). Kopnina [56] (p. 707) points out that most academic discussion does not fully explain the impact of economic development on the ecological health of the biosphere, and concludes,

The real danger of education for sustainable development is that it confuses the teacher and the student about inherent contradictions of the 'having your cake and eating it' approach. The most fundamental paradox of SD can be summed up in its oxymoronic goal of both promoting development through economic growth and re-distribution of wealth and keeping the health of the ecosystem-including humans-intact.

Bonnett [7] notes that ESD becomes enmeshed in economism, scientism, consumerism, pre-specification, managerialism-all instruments of a drive to control, exploit, and possess nature. Kopnina and Blewitt [58] conclude that ESD reflects the dominant neoliberal discourse, with its emphasis on continuing to promote open markets, equitable distribution of wealth, and social justice. They note also that aside from The Earth Charter initiative, few programs aimed at ESD explicitly address the paradoxes of sustainable development or consider the long-term implications of expanding population and wealth. Similarly, the UN Sustainable Development Goals are anthropocentric in nature and do not promote ecocentrism [63], nor do they promote a sense of wonder toward nature.

In summary, much academic discussion of ESD has been anthropocentric and steeped in neoliberal ideology. Frequently, any concern for the intrinsic value and welfare of nature, if present at all, is heavily subordinated to economism and technical fixes [7]. This needs to change to focus both on ecological ethics and a sense of wonder. Bonnett [7] argues that what lies at the heart of environmental education should be the issue of understanding the fundamental character of that environment in which we inhere, and the nature of that inherence. I would argue that involves rejuvenating our sense of wonder, or what Bonnett [7] (p. 17) calls the "ecstatic nature of emplacement." Thus, we need to re-situate ESD within the broader ambit and spirit of environmental education, where the latter is, "conceived primarily as concerned to develop a care and respect for the natural world as a bearer of intrinsic aesthetic and moral value" [7] (p. 19). One recent ray of hope in regard to the United Nations concerning ecocentrism (or a sense of wonder) comes from the UN "Harmony with Nature" programme (www.harmonywithnatureun.org), which says,

The Harmony with Nature initiative speaks to the need to move away from a human-centered worldview—or "anthropocentrism" — and establish a non-anthropocentric, or Earth-centered, relationship with the planet. 


\section{Balancing Facts with Ethics}

It is important to make clear that I am not suggesting "facts don't matter". As an environmental scientist, I have spent most of his life arguing they do matter (very much so). Hence, a key part of education must also be about teaching the reality of the environmental crisis (and yes this is pretty grim, see $[16,59,64-66])$. As Sitka-Sage et al. [39] observe, experiential education in nature does not always lead children to a more ecocentric worldview, especially as some may have been indoctrinated with anthropocentric and neoliberal worldviews most of their lives. However, experiential education in wild nature does provide the opportunity for children to develop a sense of wonder as a counter-balance to the entrenched anthropocentrism of Western society. For some this will be important, perhaps crucial in terms of transforming their worldview. Concurrent with this, of course, will have to be education about the rational arguments as to why change is needed and the solutions that exist. That requires we encourage discussion and critical thinking about the facts of the environmental crisis but also the facts about how ecosystems work. An anonymous reviewer of this article noted that education for wonder will also need to make use of different approaches that mix experiences, emotions, and also reflections on values, behavior, and on their consequences. It is a good thing to develop a spiritual bond with nature through spending time in wild nature. However, it adds to that experience to reflect on the science of how society depends on nature to survive, and also to reflect on the ethics of human actions sending many species into extinction [67].

An essential part of ecocentric education (indeed any education) must be about teaching how the world really works, as humans are fully dependent on nature to survive $[59,66]$. Most schools fail to adequately explain this in terms of food webs, energy flows, nutrient cycles and ecosystem services (though this last term in itself is anthropocentric, as it only covers services provided to humanity [2]). However, most universities also arguably fail to explain this, and do not properly encourage critical thinking through deep learning. A student can thus come out of both our schools and universities with no real knowledge of the environmental crisis and ecological reality. As Orr [25] has observed, however, graduates will be "ignorant of their ignorance". This is something both schools and universities could change fairly easily, as it is after all "factual" environmental science (if one is not in denial). However, many universities have actually gone backward in terms of their commitment to environmental science and studies (despite the fact that the environmental crisis is getting worse). It is worth remembering that environmental science demonstrates the fundamental problems caused by modernism and consumerism (which corporations that fund universities tend to adhere to). Hence, universities seem commonly to "shoot the messenger" by closing or marginalizing environmental science/studies courses, degrees and institutions. This urgently needs to be reversed.

Beyond the need to get our facts right, we have to discuss the ethics of what we are doing, and this has to be part of education at all levels. I do understand, however, that too much "doom and gloom" switches people off or makes them hopeless. They then go into denial [68]. That is why teachers at the same time need always to point out the positive and exciting solutions that do exist to the environmental crisis (e.g., $[16,24,59,64])$. 
Table 1. Steps to improve education for wonder (most adapted from [14]).

\begin{tabular}{|c|c|c|c|}
\hline Gener: & & & ommunity \\
\hline \multirow{3}{*}{$\begin{array}{l}\text { G1 All education systems should teach about how ecosystems work, } \\
\text { and also teach the science of the environment crisis. } \\
\text { G2 Society needs to examine both its worldview, as well and its } \\
\text { current anthropocentric ethics. } \\
\text { G3 Ecocentrism and ecological ethics should be foregrounded. } \\
\text { G4 Prioritise our sense of wonder as a key strategy to change } \\
\text { society's worldview and ethics, and thus help move } \\
\text { towards sustainability. } \\
\text { G5 All education should more closely engage with Indigenous } \\
\text { peoples and their lore and 'Wisdom of the Elders'. } \\
\text { G6 Make sure we 're-story' nature, that we celebrate nature in both } \\
\text { verse and prose and academic writing. } \\
\text { G7 Use visual arts and poetry/prose to explore and unfold the } \\
\text { creativity and artistry of nature. } \\
\text { G8 Faith communities can play a key role in highlighting the need } \\
\text { for education to rejuvenate our sense of wonder. } \\
\text { G9 The UN should formally adopt a strong ecocentric position, } \\
\text { in line with its 'Harmony with Nature' programme } \\
\text { (www.harmonywithnature.un.org). }\end{array}$} & \multirow{3}{*}{$\begin{array}{l}\text { S1 Accept the need for greater connection to nature } \\
\text { through experiential education, so as to solve } \\
\text { 'Nature Deficit Disorder'. } \\
\text { S2 Regularly get primary school children out into } \\
\text { nature to engage with it. } \\
\text { S2 Update education curricula/syllabuses to teach } \\
\text { ecocentric experiential education, ecological reality } \\
\text { and prioritise a sense of wonder towards nature. } \\
\text { S4 Adopt Lautensach's six major educational aims } \\
\text { to underpin a 'curriculum for ecocentric } \\
\text { value change'. } \\
\text { S5 Train all teachers to teach for wonder, and avoid } \\
\text { disenchantment when explaining sciences. } \\
\text { S6 Re-wild school playgrounds with locally-native } \\
\text { species that support a locally-evolved food web. } \\
\text { S7 Make sure that nature education, especially for } \\
\text { primary schools, is fun by using nature games on } \\
\text { field trips. }\end{array}$} & \multirow{3}{*}{$\begin{array}{l}\text { U1 All tertiary institutions should become a } \\
\text { 'wonder hub' by: } \\
\text { * Teaching the reality of the environmental crisis. } \\
\text { * Making wonder a key goal in their } \\
\text { vision/goals/mission. } \\
\text { * Getting students out into nature on field trips. } \\
\text { * Mandating courses on ecocentrism/wonder. } \\
\text { * Greater focus on courses on natural history. } \\
\text { * Ensuring that 'deep learning' includes } \\
\text { consideration of ecological ethics. } \\
\text { * Teaching how to solve problems } \\
\text { through activism. } \\
\text { * Focus on the positive solutions that protect } \\
\text { nature and help to bring us to a sustainable future. } \\
\text { U2 University education reform is needed that } \\
\text { includes 'ecological literacy', so no student can } \\
\text { graduate without a basic comprehension of } \\
\text { ecological reality. }\end{array}$} & $\begin{array}{l}\text { rrban and } \\
\text { asier for children } \\
\text { nature in } \\
\text { en. } \\
\text { s and native fish). } \\
\text { idren to display }\end{array}$ \\
\hline & & & Community (C) \\
\hline & & & \\
\hline
\end{tabular}




\section{What Are the Steps to Re-Educate for Wonder?}

What are the steps society needs to take with regard to education to revivify our sense of wonder? Table 1 lists these (most are summarized from Washington [14]). Table 1 shows there are many steps society can take to improve education for wonder. There are general steps, steps for the school education system, steps for Tertiary education, and steps for the home and the broader community. The points are numbered under each category. In the table, G1 (General point 1) makes clear the necessity of teaching about how ecosystems work, and the nuts and bolts of the environmental crisis. G2 and G3 argue the need to examine and change our worldview and ethics. It argues society should adopt ecocentrism, and an ecological ethics that accepts the intrinsic value of nature [2,3]. As part of this, humanity should respect and feel a duty of care toward nature [2]. One way to generate discussion with children would be to ask them if they think their pets, the trees outside, the birds in the garden, the animals they see on TV (or on field trips) have a right to exist for themselves? If they do, then the next step would be to ask if we should respect them, and feel a responsibility to plan for their well-being as well as ours?

G4 focuses on the need for education to foreground a sense of wonder in society. Part of this is drawing from the wealth of wisdom of Indigenous cultures [69], who lived sustainably with nature for thousands of years (G5). At the same time, we need to acknowledge the power of story in human cultures [11] and hence the need to "re-story" and celebrate nature (G6). Stories are central to all cultures, and we need to change "The Story of Nature" from a dead, lifeless machine to a vibrant, living world of which we are an inseparable part. Nabhan and Trimble [31] (p. 21) report a Cibecue Apache Elder concluded, "Stories go to work on you like arrows. Stories make you live right".

Associated with this is the use of visual arts and poetry/nature writing to bring forth the wonder of our natural world (G7). It is also worth acknowledging the power of the many faith communities around the world, which if they were to foreground a sense of wonder in their education, could make a major impact in advancing ecocentric education (G8). One other key way to foreground ecocentrism and wonder would be for the United Nations to build on their already excellent "Harmony with Nature" Programme (www.harmonywithnatureun.org) (G9) by formally adopting an ecocentric position that supports education for wonder.

In regard to the steps for schools, society needs to accept the reality of "Nature Deficit Disorder" [12]. Hence, the need for much greater connection by students (especially before age 12) with nature via experiential outdoor education (S1). That means regularly taking primary school children out into wild nature (S2), as happens in Finland [36]. There is clearly a need for change in our education curricula and syllabuses to foreground ecocentric experiential education (S3). A naturalistic and environmental education is needed that would design its curriculum not to satisfy industry but to reclaim relations with wild nature [34]. Adopting Lautensach's [33] six major education aims to underpin a "curriculum for ecocentric value change" can assist here (S4). These are [33],

1. Adopt a concept of progress that is informed by sustainability;

2. Replace anthropocentrism with an ecocentric ethic;

3. Acquire the cognitive and affective skills of eco-literacy to collaboratively meet the challenges;

4. Acquire a vision for, and awareness of, the future that includes change and sustainable solutions;

5. Adopt a non-parochialist view of environmental values and academic inquiry;

6. Become liberated from exploitative dependencies.

To assist in curricula change, we need to train teachers to teach for wonder and avoid disenchanting children from nature by portraying it as dead or mechanical [22] (S5). What we have learned about the Universe is (after all) quite wondrous (e.g., [70]). Many noted scientists have remarked that plenty of mystery still remains in science, and Einstein [71] (p. 7) noted, "The most beautiful experience we can have is the mysterious. It is the fundamental emotion that stands at the cradle of true art and true science." One practical strategy schools can undertake is to improve 
the presence of nature in schools by re-wilding their school grounds with locally native plants (S6). Another aspect that may be forgotten in education is that (where possible) it should be fun (especially for primary students) through the use of nature games [37] in school and on field trips (S7).

University, indeed all Tertiary institutions, have the opportunity to re-invent themselves as "wonder hubs" by a whole suite of actions listed in point U1. Key among these would be foregrounding education for wonder in their vision/goals and mission statements. Having never been done before (that I am aware of), such a process would assist universities to become champions for education about a sense of wonder toward nature. This is not to say that good things are not happening at universities that relate to education for wonder. For example, in the US, Penn's Green Campus Partnership developed a "Sustainability Course Inventory", a comprehensive listing of all sustainability-focused and sustainability-related courses [72]. This involved seeking to draw out students' understanding for the many facets of sustainability and their own "affinity for life" [72] (p. 658). However, this did not actually involve experiential education in wild nature. However, Couper and Porter [73] describe an auto-ethnography approach with geography students undertaking an "Outdoor Practice 2" module. They asked students questions on the way to the climbing site about what was around them, and their experiences, encouraging them to take notice and to think. The students then kept a journal that, "drew on their experiences with others and the environment, but giving them scope to define and focus that for themselves" [73] (p. 213). Responses ranged from anthropocentric to ecocentric, but the exercise succeeded in focusing students on their connection to nature, which for some led to consideration of the need for respect, and a duty of care, toward nature [73].

However, one of the most promising approaches is that by Goralnik et al. [15] regarding an "environmental pedagogy of care" that uses a "field philosophy" that seeks to include an emotional component in ethics learning. They note this is contrary to most traditional academic approaches to philosophical education. While their focus is on care, they also mention wonder. They feel that learning must be both an emotional and an intellectual experience. They argue that a synthesis of experiential education, emotional engagement, and the ethic of care, can inform a meaningful pedagogy for experiential environmental humanities learning, an environmental pedagogy of care. They conclude that the goal of the ethic of care is [15] (p. 420),

To integrate it as a guiding morality in the classroom and as a bridge to the beyond-school world it can lead students to right action on behalf of the beings, places, and ideas they value in relationship.

Their environmental pedagogy of care is thus seen as a motivator for students to take action to protect nature [15]. If such a "pedagogy of care" was widely adopted by universities, it would greatly assist education for wonder, and could radically assist in turning universities into "wonder hubs".

Teaching how to solve environmental problems through activism is also important. This is something that Maniates [74] notes universities mostly steer clear of, as it is deemed "political". There is also the important strategy of a focus on the positive solutions that both protect nature and lead towards a sustainable future (even though they may also be challenging) [16,64]. Another key strategy (U2) is the education reform suggested by David Orr [75] where universities focus on "ecological literacy" so that no student could graduate without an understanding of ecological reality. Orr argued that such ecological literacy should include an understanding of the following items [75]:

- the law of thermodynamics;

- the basic principles of ecology;

- carrying capacity;

- energetics;

- least cost, end use analysis;

- how to live well in place;

- limits to technology; 
- $\quad$ appropriate scale;

- $\quad$ sustainable agriculture and forestry;

- $\quad$ steady state economics;

- environmental ethics.

As Louv [12] notes, a sense of wonder and joy in nature should be at the very center of such ecological literacy.

There are also strategies that can improve education for wonder in the home. The first is in regard to how society plans its cities, suburbs and houses [12]. Changing society's house, urban and suburban design can make it easier for children to engage with nature (H1). There are also many things home-owners can do to encourage a sense of wonder (H2), such as to plant locally-native species [36]. Similarly, the community can take strong action to improve children getting out into wild nature, through institutions such as Nature Clubs and Life Centers [45] (C1). Another important process the community can support is the promotion of adolescents undertaking (around the time of puberty) "Rites of Passage" in wild nature, such as Vision Quests (C2) [14].

There are thus many steps that can be taken at various levels to improve education for wonder toward nature. Some need government involvement (e.g., curricula), some need school or university support, while others can be done in the home or in the community at large. The evidence to date shows that there has not been a concerted approach within society to educate for wonder. However, the sheer variety of strategies and possibilities available indicates that there are many excellent steps we can take to immediately improve this.

\section{Conclusions}

The sense of wonder at nature is arguably already present in all children-it just needs to be encouraged to unfold by allowing children access to wild nature, thus avoiding "Nature Deficit Disorder". If one can get children into wild nature, they do respond. Similarly, if wonder gets buried during puberty, then nature rituals, tertiary education, and continuing education for adults can help resurrect this and rejuvenate it. The power and wonder of natural places can assist adults with this. So, the path to improving education for wonder is clear-what is now needed is the personal, social, institutional and political will. Like all change, that is going to depend on what we collectively speak out for. It will depend on whether we foreground education for wonder at all levels. This is a key challenge—and solution—of our times.

This paper argues strongly that we will not solve the environmental crisis (and reach a sustainable future) without a change in worldview to ecocentrism and a rejuvenation of humanity's sense of wonder toward nature. This is not to suggest that these are the only key changes necessary to reach a sustainable future. There is also an urgent need for other key actions, such as moving to an ecological economics (e.g., [76,77]) as well as acting on overpopulation (e.g., [78]) and overconsumption (e.g., [79]). However, ecocentrism and a sense of wonder are rarely foregrounded as key solutions via education, hence why they are the focus in this paper. Yet society (and the majority of academia) remains strongly anthropocentric - as does our education system. Making education more ecocentric, and teaching in a way that encourages a sense of wonder at nature, are thus crucial to any serious change. Schools have the ability to get children out into nature on field trips and camps (as Finland commonly does). However, many fail in this, as they tend to reflect the dominant worldview (anthropocentrism). Schools are, to a large extent, bound in what they teach by curricula and syllabuses. However, parents (and citizens in general) can lobby government for these to be improved to engage children more with nature and to discuss ecocentric ethics and the intrinsic value of nature.

Several different aspects of education for wonder lie beyond the school system. Education for wonder in the home can be expanded. Education for wonder in the community can be strongly expanded, for example through local Nature Clubs and Life Centers. In fact, community action for wonder may be as important as that in the education system and is something the "grassroots" can undertake without waiting for governments to act. Education for wonder at the university level 
needs to be massively expanded to turn them into "wonder hubs" (as well as sustainability hubs) that teach an ecocentric education that encourages discussion about the dominance of anthropocentrism in society. Part of this is through teaching a more holistic EE, rather than an ESD that at times encourages the idea of hubristic "mastery" over nature.

Arguably, the key goal of education should be to get students "to think for themselves" rather than to repeat things by rote (just to pass an exam). Indeed, such critical thinking is the basis of deep learning in education. However, a sense of wonder tells us that it is not just about thinking, it is also about feeling. People also need to be able to feel for themselves, but also to feel for the rest of life. While education pretends it is only about "facts" it will fail to effectively lead us to a sustainable future, as it ignores that it also needs to be about ethics. We need to discuss what is right and what is wrong in what we are doing to the world. Indeed, education needs to be about caring, for ourselves and our society, but also for future generations, and the rest of life on planet Earth—our kin. An "ethic of care" is clearly part of education for wonder. It is time to entwine social justice and ecojustice, so we act on both. Hence, an ecocentric environmental education will ask questions about worldview, ethics, values, and justice. This is something we need deeply to both think—and feel-about.

Finally, given the many problems society faces, we need to understand that one positive and exciting solution to the environmental crisis is right before us. This is changing our education system, which is arguably a pre-condition for reaching an ecologically sustainable society. Hence, we need to teach about ecological reality, ecosystem functions, ecological ethics, and a sense of wonder toward nature. If we change the education system to become a champion for these, then the world could change very quickly for the better. Time for a key step forward-through education for wonder.

Funding: This research received no external funding.

Acknowledgments: I would like to thank my anonymous reviewers for their helpful comments. I would also like to thank a variety of scholars for relevant discussions over several years that relate to this topic. These include Helen Kopnina (Hague University of Applied Science); Eileen Crist (Virginia Tech); John Seed (Rainforest Information Centre); Bron Taylor (University of Florida); Patrick Curry (The Ecological Citizen); and Jack Piccolo (Karlstad University).

Conflicts of Interest: The author declares no conflict of interest.

\section{References}

1. Bonnett, M. Environmental education and the issue of nature. J. Curr. Stud. 2007, 39, 1-11. [CrossRef]

2. Washington, H.; Taylor, B.; Kopnina, H.; Cryer, P.; Piccolo, J. Why ecocentrism is the key pathway to sustainability. Ecol. Cit. 2017, 1, 35-41.

3. Curry, P. Ecological Ethics: An. Introduction, 2nd ed.; Polity Press: Cambridge, UK, 2011.

4. Norris, K.S.; Jacobson, S.K. Content analysis of tropical conservation education programs: Elements of success. Environ. Educ. 1998, 30, 38-44. [CrossRef]

5. Goodall, J. Caring for People and Valuing Forests in Africa. In Protecting the Wild: Parks and Wilderness, The Foundation for Conservation; Wuerthner, G., Crist, E., Butler, T., Eds.; The Island Press: Washington, DC, USA, 2015; pp. 21-26.

6. Glasser, H. Learning Our Way to a Sustainable and Desirable World: Ideas Inspired by Arne Naess and Deep Ecology. In Higher Education and the Challenge of Sustainability: Problematics, Promises, and Practice; Corcoran, P.B., Wals, A.E.J., Eds.; Springer: Dordrecht, The Netherlands, 2004; pp. 131-148.

7. Bonnett, M. Sustainable development, environmental education, and the significance of being in place. Curr. J. 2013, 24, 1-22. [CrossRef]

8. Kopnina, H.; Cherniak, B. Neoliberalism and Justice in Education for Sustainable Development: A call for inclusive pluralism. Educ. Res. 2016, 22, 827-841. [CrossRef]

9. Gorski, P.C. Critical Ties: The Animal Rights Awakening of a Social Justice Educator. Available online: http:/ / www.edchange.org/publications/animal-rights-social-justice.pdf (accessed on 11 June 2017).

10. Kopnina, H.; Gjerris, M. Are some animals more equal than others? Animal Rights and Deep Ecology in environmental education. J. Environ. Educ. 2015, 20, 109-123.

11. Abram, D. Becoming Animal: An. Earthly Cosmology; Vintage Books: New York, NY, USA, 2010. 
12. Louv, R. Last Child. in the Woods: Saving our Children from Nature-Deficit Disorder; Atlantic Books: London, UK, 2005.

13. Louv, R. The Nature Principle: Reconnecting with Life in a Virtual Age; Algonquin Books: Chapel Hill, NC, USA, 2011.

14. Washington, H. A Sense of Wonder Towards Nature: Healing the World through Belonging; Routledge: London, UK, 2018.

15. Goralnik, L.; Millenbah, K.; Nelson, M.; Thorp, L. An environmental pedagogy of care: Emotion, relationships, and experience in higher education ethics learning. J. Exp. Educ. 2012, 35, 412-428.

16. Washington, H. Demystifying Sustainability: Towards Real Solutions; Routledge: London, UK, 2015.

17. Ecuyer, C. The wonder approach to learning. Front. Hum. Neurosci. 2014, 8, 1-8.

18. Washington, H. Sharing stories of deep connection. Ecol. Cit. 2017, 1 (Suppl. A), 5-6.

19. Tacey, D. Re-enchantment: The New Australian Spirituality; Harper-Collins Publishers: Sydney, Australia, 2000.

20. Schinkel, A. The educational importance of deep wonder. J. Phil. Educ. 2017, 51, 538-553. [CrossRef]

21. Shepard, P. Nature and Madness; University of Georgia Press: London, UK, 1982.

22. Vetlesen, A. The Denial of Nature: Environmental Philosophy in the Era of Global Capitalism; Routledge: London, UK, 2015.

23. Crist, E. Abundant Earth and the population question. In Life on the Brink: Environmentalists Confront Overpopulation; Cafaro, P., Crist, E., Eds.; University of Georgia Press: Athens, GA, USA, 2012; pp. 141-151.

24. Washington, H. Positive Steps to a Steady State Economy; CASSE NSW: Sydney, Australia, 2017; Available online: https:/ / steadystatensw.files.wordpress.com/2017/06/posstepsroyal11ptjustheaderfinaljune12thebooklowres. pdf (accessed on 1 July 2018).

25. Orr, D. Earth in Mind: On Education, Environment and the Human Prospect; Island Press: Washington, DC, USA, 1994.

26. Cobb, E. The Ecology of Imagination in Childhood. Daedalus 1959, 88, 537-548.

27. Trimble, S. A wilderness with cows. In The Geography of Childhood: Why Children need Wild Places; Nabhan, G., Trimble, S., Eds.; Beacon: Boston, MA, USA, 1994.

28. Chawla, L. Learning to love the natural world enough to protect it. Barn 2006, 2, 57-78.

29. STW. 'Schooling the World' Documentary 2010 (Directed by Carol Black). Available online: https: / / www. youtube.com/watch? $\mathrm{v}=\mathrm{oDxYWspiN-8}$ (accessed on 3 July 2018).

30. Østergaard, E.; Dahlin, B.; Aksel, H. Doing phenomenology in science education: A research review. Stud. Sci. Educ. 2008, 44, 93-121. [CrossRef]

31. Nabhan, G.; Trimble, S. The Geography of Childhood: Why Children Need Wild Places; Beacon Press: Boston, MA, USA, 1994.

32. Kelly, A.V. The Curriculum: Theory and Practice, 6th ed.; Sage Publications: London, UK, 2009.

33. Lautensach, A. Learning for biosphere security in a crowded, warming world. Ecol. Cit. 2018, 1, 171-8.

34. Fisher, A. Radical Ecopsychology: Psychology in the Service of Life; State University of New York Press: Albany, NY, USA, 2013.

35. Wells, N.; Leckies, K. Nature and the life course: Pathways from childhood nature experiences to adult environmentalism. Child. Youth Environ. 2006, 16, 1-24.

36. Jeronen, E.; Jeronen, J. Outdoor education in Finland. Stud. Socio-Econ. Hum. 2012, 2, 152-160.

37. Cornell, J. Sharing Nature with Children; Dawn Publications: Nevada, CA, USA, 1998.

38. Young, J.; McGown, E.; Haas, E. Coyote's Guide to Connecting to Nature; Owlink Media: Shelton, WA, USA, 2010.

39. Sitka-Sage, M.; Kopnina, H.; Blenkinsop, S.; Piersol, L. Rewilding education in troubled times; Or, getting back to the wrong post-nature. Vis. Sustain. 2017, 8, 20-37.

40. Cullinan, C. Wild Law: A Manifesto for Earth Justice; Green Books: Totnes/Devon, UK, 2003.

41. Rolston III, H. A New Environmental Ethics: The Next Millennium for Life on Earth; Routledge: New York, NY, USA, 2012.

42. Macy, J.; Brown, M. Coming Back to Life: The Updated Guide to the Work that Reconnects; New Society Publishers: Gabriola Island, BC, Canada, 2014.

43. RIC 'The Council of All Beings Workshop Manual', Rainforest Information Centre Website, Deep Ecology Section. Available online: http://www.rainforestinfo.org.au/deep-eco/cabcont.htm (accessed on 1 July 2018). 
44. Putnam, R. Bowling Alone: The Collapse and Revival of American Community; Simon and Schuster: New York, NY, USA, 2000.

45. Boyden, S. The Biology of Civilisation: Understanding Human Culture as a Force in Nature; UNSW Press: Sydney, Australia, 2004.

46. Francis, Pope. Laudato Si Encyclical, Para 33. 2015. VATICAN Website 'The Holy See'. Available online: http:/ / w2.vatican.va/content/francesco/en/encyclicals/documents / papa-francesco_20150524_ enciclica-laudato-si.html (accessed on 01 July 2018).

47. IUCN. IUCN Guidelines for Applying Protected Area Management Categories; Dudley, N., Ed.; International Union for Conservation of Nature: Gland, Switzerland, 2008.

48. Oelschlaeger, M. The Idea of Wilderness: From Prehistory to the Age of Ecology; Yale University Press: New Haven, CT, USA; London, UK, 1991.

49. Harper, S. The way of wilderness. In Ecopsychology: Restoring the Earth, Healing the Mind; Roszak, T., Gomes, M., Kanner, A., Eds.; Sierra Books: San Francisco, CA, USA, 1995; pp. 183-200.

50. Weber, A. The Biology of Wonder: Aliveness, Feeling, and the Metamorphosis of Science; New Society Publishers: Lillooet, BC, Canada, 2016.

51. Nabhan, G. Going truant: The invitation of young naturalists. In The Geography of Childhood: Why Children Need Wild Places; Nabhan, G., Trimble, S., Eds.; Beacon Press: Boston, MA, USA, 1994; pp. 33-52.

52. Abram, D. The Spell of the Sensuous; Vintage Books: New York, NY, USA, 1996.

53. Bonnett, M. Normalizing catastrophe: Sustainability and scientism. Environ. Educ. Res. 2013, 19, $187-197$. [CrossRef]

54. Nabhan, G. Children in touch, creatures in story. In The Geography of Childhood: Why Children Need Wild Places; Nabhan, G., Trimble, S., Eds.; Beacon Press: Boston, MA, USA, 1994.

55. Jickling, B.; Wals, A. Globalization and environmental education: Looking beyond sustainable development. J. Curr. Stud. 2008, 40, 1-21. [CrossRef]

56. Kopnina, H. Education for sustainable development (ESD): The turn away from "environment" in environmental education? Environ. Educ. Res. 2012, 18, 699-717. [CrossRef]

57. Kopnina, H. Metaphors of nature and development: Reflection on critical course of sustainable business. Environ. Educ. Res. 2015, 22, 571-589. [CrossRef]

58. Kopnina, H.; Blewitt, J. Sustainable Business: Key Issues; Routledge: London, UK, 2015.

59. Washington, H. Human Dependence on Nature: How to Help Solve the Environmental Crisis; Earthscan: London, UK, 2013.

60. Wals, A. Learning our way to sustainability. J. Educ. Sustain. Dev. 2011, 5, 177-186. [CrossRef]

61. UNEP and UNESCO. The Belgrade Charter. United Nations Environment Programme (UNEP) and United Nations Educational, Scientific and Cultural Organization (UNESCO). 1976. Available online: http: / / unesdoc.unesco.org/images/0001/000177/017772eb.pdf;http:/ / www.medies.net/_uploaded_ files/The-BelgradeCharter.pdf (accessed on 1 August 2018).

62. Spring, J. How Educational Ideologies are Shaping Global Society: Intergovernmental Organizations, NGO's, and the Decline of the State; Lawrence Erlbaum: Mahwah, NJ, USA, 2004.

63. Kopnina, H. The victims of unsustainability: A challenge to sustainable development goals. Int. J. Sustain. Dev. World Ecol. 2016, 23, 113-121. [CrossRef]

64. Brown, L. World on the Edge: How to Prevent Environmental and Economic Collapse; W.W. Norton and Co.: New York, NY, USA, 2011.

65. Wijkman, A.; Rockstrom, J. Bankrupting Nature: Denying our Planetary Boundaries; Routledge: London, UK, 2012.

66. Oliver, T.H.; Isaac, N.J.B.; August, T.A.; Woodcock, B.A.; Roy, D.B.; Bullock, J.M. Declining resilience of ecosystem functions under biodiversity loss. Nat. Commun. 2015, 6, 1-8. [CrossRef] [PubMed]

67. Cafaro, P.; Primack, R. Species extinction is a great moral wrong. Biol. Conserv. 2014, 170, 1-2. [CrossRef]

68. Washington, H. Denial-the key barrier to solving climate change. In Encyclopedia of the Anthropocene; DellaSala, D.A., Goldstein, M.I., Eds.; Elsevier: Duxford, UK, 2018; pp. 493-499.

69. Knudtson, P.; Suzuki, D. Wisdom of the Elders; Allen and Unwin: Sydney, Australia, 1992.

70. Swimme, B.; Berry, T. The Universe Story: From the Primordial Flaming Forth to the Ecozoic Era; Harper Books: San Francisco, CA, USA, 1992.

71. Einstein, A. Living Philosophies; Simon and Schuster: New York, NY, USA, 1931. 
72. Dmochowski, J.; Garofalo, D.; Fisher, S.; Greene, A.; Gambogi, D. Integrating sustainability across the university curriculum. Int. J. Sustain. High. Educ. 2016, 17, 652-670. [CrossRef]

73. Couper, P.; Porter, S. "Environmental awareness" and rock climbing: Changing pedagogies to enhance pro-environmental graduate attributes. J. Geogr. High. Educ. 2016, 40, 207-221. [CrossRef]

74. Maniates, M. Teaching for turbulence. In State of the World 2013: Is Sustainability Still Possible? Starke, L., Ed.; Island Press: Washington, DC, USA, 2013; pp. 255-268.

75. Orr, D. What Is Education for? Six Myths about the Foundation of Modern Education, and Six New Principles to Replace Them. Available online: http:/ / www.context.org/iclib/ic27/orr/ (accessed on 5 July 2018).

76. Dietz, R.; O'Neill, D. Enough is Enough: Building a Sustainable Economy in a World of Finite Resources; Berrett-Koehler Publishers: San Francisco, CA, USA, 2013.

77. Daly, H. From Uneconomic Growth to the Steady State Economy; Edward Elgar: Cheltenham, UK, 2014.

78. Crist, E.; Mora, C.; Engelman, R. The interaction of human population, food production, and biodiversity protection. Science 2017, 356, 260-264. [CrossRef] [PubMed]

79. Assadourian, E. Re-engineering cultures to create a sustainable civilization. In State of the World 2013: Is Sustainability Still Possible? Starke, L., Ed.; Island Press: Washington, DC, USA, 2013.

(C) 2018 by the author. Licensee MDPI, Basel, Switzerland. This article is an open access article distributed under the terms and conditions of the Creative Commons Attribution (CC BY) license (http:/ / creativecommons.org/licenses/by/4.0/). 